I suggest that to place one claiming to do so in the hands of many who will fail to appreciate its limitations would be of little service to the cause of safe navigation.

Radio Advisory Service,

Cory Buildings,

I 7 Fenchurch Street,

London, E.C.3.
Yours faithfully,

F. J. WYLIE.

SIR,

Whilst not wishing to prolong correspondence on 'Radar Usage \& Speed in Fog', may I refer to the remark of Captain Robb in his letter: 'Thou shalt not be found out'? I have held that a man is not in legal jeopardy until he is before a court, and he won't appear there unless he has (in this instance) collided. Near misses and unconventional tactics, though from a seaman's view reprehensible, will not ensure his arrival at the place of retribution; in short, if collision is avoided even by non-adherence to the Rule of the Road, repercussions are unlikely. It may be bad seamanship to stop when in doubt and let the other vessel contemplate the circumstances but I feel it is a sounder procedure than to steam along assuming knowledge one doesn't possess. 'Thou shalt not be found out' is a good commandment, and you won't be unless you collide. Some years ago, in broad daylight, I missed a ship by the thickness of a visiting card. I am uncertain of her nationality, but about i4 different tongues called down blessings on my head till I went into the chart house and shut the door. But for a millimetre, I would be writing you from Dartmoor, but, of course, there was no collision and I wasn't found out, Rule of the Road notwithstanding.

Legally, I believe, a near miss is tantamount to collision, since the essence of faulty navigation is there and, in event of collision, the extent of damage is immaterial to the navigational offence; but the guilty navigator who misses fortunately misses publicity too.

Mill View,

Outwood,

Redhill.
Yours faithfully,

RoNAld G. Bolton.

\title{
LE RADAR DE NAVIGATION
}

SIR,

In my review of Le Radar de Navigation (Vol. V, p. 96) I wrote that the book was '. . . the work of a philosopher rather than a navigator; of a man who reaches his conclusions by reflection rather than from experience'. Since the time of writing my attention has been drawn to the fact that Professor Hugon, the author, has had considerable seagoing experience, much of it in command of French naval vessels. I would like, therefore, to correct any false impression my review may have given of the author's qualifications. I may perhaps add that the point I had in making my remark was to congratulate the author on coming to conclusions which few users of radar would dispute.

I am, Sir, Your Reviewer, L. S. L. 